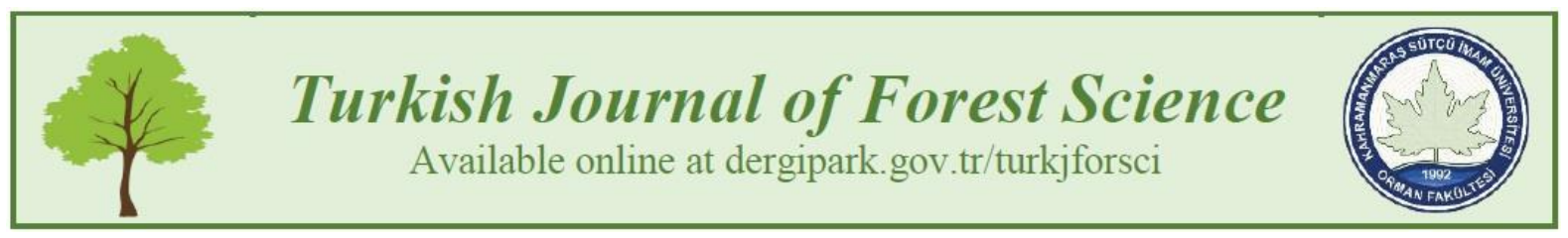

\title{
A STUDY ON OFFICE PAPER PRODUCTION FROM PRIMARY AND SECONDARY FIBERS
}

\author{
Mustafa CICEKLER $^{1, *}$, Ahmet TUTUS ${ }^{1}$ \\ ${ }^{1}$ Department of Forest Industry Engineering, Kahramanmaras Sutcu Imam University, Kahramanmaras \\ "Corresponding author: mcicekler87@gmail.com
}

Mustafa CICEKLER: https://orcid.org/0000-0001-5793-2827

Ahmet TUTUS: https://orcid.org/0000-0003-2922-4916

Please cite this article as: Cicekler, M. \& Tutus, A. (2021) A study on office paper production from primary and secondary fibers, Turkish Journal of Forest Science, 5(2), 433-444

\author{
ESER BILGISI / ARTICLE INFO \\ Araştırma Makalesi / Research Article \\ Geliş 17 Haziran 2021 / Received 17 June 2021 \\ Düzeltmelerin gelişi 10 Agustos 2021 / Received in revised form 10 August 2021 \\ Kabul 8 Eylul 2021 / Accepted 8 September 2021 \\ Yayımlanma 31 Ekim 2021 / Published online 31 October 2021
}

\begin{abstract}
This study deals with the utilization of primary and secondary fibers for the office paper production. Pinus brutia (BF) and wheat straws pulps (WF) were used as primary fiber (PF), and mixed office wastes pulps were used as secondary fiber (SF). PFs were obtained from $P$. brutia chips and wheat straws by using kraft and soda-air cooking methods, respectively. Mixed office wastes were recycled according to International Association of the Deinking Industry (INGEDE) standards. Enzyme (X), oxygen $(\mathrm{O})$, alkali extraction (E), hypochlorite $(\mathrm{H})$, and formamidine sulphinic acid $(\mathrm{F})$ bleaching stages were applied to $\mathrm{PF}$ and $\mathrm{SF}$. The PF and SF were bleached in six stages (XOEHEH) and in three stages (XOF), respectively. Bleached PF and SF were blend in different rates (SF: 70-100\%, BF and WF: 0$30 \%$ ) and office papers were produced. Mechanical and optical properties of the papers were determined according to relevant standards. The highest mechanical properties (breaking length: $3.58 \mathrm{~km}$, burst index: $1.51 \mathrm{kPa} \cdot \mathrm{m}^{2} \mathrm{~g}^{-1}$ ) were obtained from $70 \% \mathrm{SF}, 25 \% \mathrm{WF}$, and $5 \%$ BF blends. Papers produced only with SFs have the highest optical properties (Whiteness: 80.65 ISO\%, Brightness: 94.02 ISO\%, Yellowness: -20.16 E313). However, in terms of both mechanical and optical properties, office paper can be produced from six different PF and SF blends according to the relevant standards.
\end{abstract}

Keywords: Primary fiber, secondary fiber, pulping, recycling, office paper

\section{BİRINCİL VE İKINCILL LIFLERDEN OFİS KAĞIDI ÜRETIMİ ÜZERINE BİR ARAŞTIRMA}

ÖZET: Ofis kağıdı üretiminde birincil ve ikincil liflerini değerlendirilmesini ele almıştır. Kızılçam (BF) ve buğday sapı (WF) lifleri birincil lif (PF) olarak atık ofis kağıt hamurları ise ikincil lif (SF) olarak kullanılmıştır. Birincil lifler kızılçam odunundan kraft yöntemi ile buğday saplarından ise soda-hava yöntemiyle üretilmiştir. Atık ofis kağıtlarından ikincil lif üretimi 
Uluslararas1 Mürekkep Giderme Endüstrisi Birliği (INGEDE) standartlarına göre gerçekleştirilmiştir. PF ve SF ağartmalarında enzim (X), oksijen $(\mathrm{O})$, alkali ekstraksiyonu (E), hipoklorit $(\mathrm{H})$ ve formamidin sülfinik asit $(\mathrm{F})$ ağartma kademeleri kullanılmıştır. Birincil lifler altı kademede (XOEHEH), ikincil lifler ise üç kademede (XOF) ağartılmıştır. Ağartılmış PF ve SF farklı karışım oranlarında (SF: \%70-100, PF: \%0-30) harmanlanarak ofis kağıtları üretilmiştir. Üretilen ofis kağıtlarının mekanik ve optik özellikleri ilgili standartlara bağlı kalınarak belirlenmiştir. En yüksek mekanik özellikler (kopma uzunluğu: $3.58 \mathrm{~km}$, patlama indisi $1.51 \mathrm{kPa}^{2} \mathrm{~m}^{-1}$ ) \%70 ikincil lif ve \%30 birincil lif (\%25 WF ve \%5 BF) karışımlarından üretilen ofis kağıtlarında tespit edilmiştir. En yüksek optik özellikleri (beyazlık: 80.65 ISO\%, parlaklık: 94.02 ISO\%, sarılık: -20.16 E313) ise sadece SF kullanılarak üretilen ofis kağıtları göstermiştir. Sonuç olarak, hem mekanik hem de optik özellikler açısından ofis kağıdı, ilgili standartlara göre altı farklı PF ve SF karışımından üretilebilmektedir.

Anahtar kelimeler: Birincil lif, ikincil lif, kağıt hamuru, geri dönüşüm, ofis kağıdı

\section{INTRODUCTION}

The term "office paper" refers to a number of paper products used in offices and business, such as writing, computer, and copying papers. These grades are brighter and have longer fibers than the newspaper and packaging grades. Office paper is typically white, but it is available in a variety of colors (Borthers et al., 1994). The majority of office paper is made of primary fibers $(\mathrm{PF})$, which are produced from wood with using chemically cooking methods. However, as the use of personal computers has grown in the last six years, the generation of office paper has decreased. Since 1960, office paper recycling has increased, and the recycling rate has more than quadrupled (Viesturs et al., 1999).

According to the Confederation of European Paper Industries (CEPI) Annual Statistics, Europe's paper recycling rate increased from $40.8 \%$ in 1991 to $71.5 \%$ in 2015 . The recovered paper grades with the highest utilization rates are case materials (93.9\%) and newsprint (92.8\%). The office waste paper (defined as "other graphic papers" according to CEPI) had the lowest utilization rate (12.8\%) (CEPI, 2021).

The main limitation in the use of mixed waste wastes as secondary fiber (SF) for the manufacture of high-quality recycled paper is that it contains a high proportion of hard to deink non-impact printed (laser and xerographic) papers, spanning between 50\% and 80\% (Olson et al., 1993; Tsatsis et al., 2017). Many types of waste paper are subjected to deinking in order to remove ink while preparing for new paper production. A variety of deinking technologies can be used depending on the type of paper coming into the system and the requirements in the final product. The most common processes used for deinking are flotation, washing and bleaching (Scheldorf \& Strand, 1996; Pesman, 2010).

In the flotation method, ink removal is carried out by introducing air into the recovered pulp and adding surface active chemicals. Hydrophobic (water-repellent) components such as ink particles are brought to the surface with the help of air, and then these components are removed from the surface with the help of scraping. Recently, the use of the flotation process during the recycling of papers to be used for the white layer in the production of corrugated cardboard has become increasingly common (Morel, 1989; Cleveland, 1993; Borchard, 1999). Hemicellulase, cellulase, lipase, esterase, pectinase and ligninolytic enzymes are generally used in deinking 
processes (Bajpai et al., 1999). Enzymatic approaches involve interaction with the fiber surface or ink. Pectinase, hemicellulase, cellulase and ligninolytic enzymes break the bonds on the fiber surface or close to the ink particles and facilitate the removal of inks by washing or flotation. Lipase and esterase enzymes degrade vegetable oil-based inks and remove them from the environment (Eom \& Ow, 1990; Woodward \& ark., 1994; Welt \& Dinus, 1995; Bajpai et al., 1999).

In the bleaching process of SF, the colorants in the inks are destroyed and the brightness value of the pulp is increased by using bleaching chemicals such as FAS, hydrogen peroxide and sodium dithionite. This process is applied during pulping or after pulping to recycled pulp and used in the production of tissue, office and newsprint papers at desired brightness levels (Ferguson, 1992; McCool, 1993). In the bleaching process of PF, Enzyme treatment (X) is an environmentally friendly biological bleaching method and is used to prevent or reduce the use of chlorine. The most effective and common enzyme used in enzymatic bleaching is xylanase. Xylanase breaks the covalent bonds between hemicellulose and lignin in the pulp, revealing lignin and chromophores. In addition, xylan, which is re-precipitated on the fibers after the cooking process, ensures repolymerization and facilitates the population of bleach chemicals in the next bleaching stages (Senior \& Hamilton, 1991; Tolan \& Canovas, 1992; Thibault et al., 1999; Bajpai et al., 1999; Zhan et al., 2000).

All of the bleached fibers used for the office paper production in Turkey are imported from another countries. Besides, when the production and consumption amounts of office paper in Turkey are compared, 350.000 tons of production was realized in 2019, while the consumption amount is 3.5 times more than this and is approximately 1.25 million tons (FAO, 2021). Regarding these data, Turkey imports both raw material and final product for office paper. Therefore, our country is completely dependent on the other countries in terms of office paper. Since Turkey is dependent on foreign countries for the supply of bleached cellulose, the price of cellulose has increased approximately 3 times in three years due to the fluctuations in the exchange rate. Considering that the amount of office paper produced is approximately 350 thousand tons, this difference makes a serious economic sense.

The aim of this study is to evaluate the mixed office wastes (MOW) in the office papers production by using PF produced from wood and annual plants. Besides, it is aimed to determine more economical and ecological methods in the pulp production and paper obtained from this fiber blends, compared to wood fiber, and to obtain new products with the characteristics of papers obtained from natural wood.

\section{MATERIALS AND METHODS}

\section{Materials}

In this study, Turkish Pine (Pinus brutia) wood, which has a wide distribution area in Turkey and obtained from Kahramanmaraş-Ahır Mountain, was used as wood raw material. During the selection of the trial trees, attention was paid to ensure that the trees did not have extreme structural features. Wheat (Triticum aestivum L.) straws, whose trade name is Ceyhan 99, which is one of the annual plants with the widest distribution area in Turkey, were used as research material. The straws were obtained from the trial fields of Kahramanmarass East Mediterranean Transitional Zone Agricultural Research of Institute. Roll papers printed (flexo) 
using solvent based ink were supplied from Kombasssan Paper Inc., and used as mixed office wastes in the study. The printing model applied to the test papers as a result of the interviews with the Marmara University Printing Department and the examination of the scientific studies on the subject.

The sodium hydroxide $(\mathrm{NaOH})$, sodium sulfide $\left(\mathrm{Na}_{2} \mathrm{~S}\right)$, sodium carbonate $\left(\mathrm{Na}_{2} \mathrm{CO}_{3}\right)$, potassium borohydride $\left(\mathrm{KBH}_{4}\right)$, hydrogen peroxide $\left(\mathrm{H}_{2} \mathrm{O}_{2}\right)$, oleic acid, sodium silicate $\left(\mathrm{Na}_{2} \mathrm{SiO}_{3}\right)$, calcium chloride $\left(\mathrm{CaCl}_{2}\right)$, magnesium sulfate $\left(\mathrm{MgSO}_{4}\right)$, formamidine sulfinic acid (FAS), sodium hypochlorite $(\mathrm{NaClO})$ were supplied by Merck. Xylanase and cellulase enzymes were purchased from Sigma Aldrich. Distilled water was used in whole experiments.

\section{Primary Fiber Production}

The brutia woods were chipped into $25-35 \mathrm{~mm}$ length, 3-7 mm thickness and contaminants and dusts were removed. Air-dried wheat straws were cut into pieces about 6-8 cm long and cleaned from leaves and non-fibrous materials. The cooking conditions of brutia wood chips and wheat straws were presented in Table 1.

Table 1. Cooking Conditions for Primary Fiber Production

\begin{tabular}{lclc}
\hline P. Brutia Wood Chips Cooking Condition & & Wheat Straws Cooking Condition & \\
\hline Active Alkali Charge (\%) & 20 & NaOH charge $(\%)$ & 14 \\
Sulfidity Charge $(\%)$ & 27 & Air Pressure (bar) & 9 \\
Total Titratable Alkali Charge $(\%)$ & 26 & $\mathrm{KBH}_{4}$ Charge $(\%)$ & 0.7 \\
$\mathrm{KBH}_{4}$ Charge $(\%)$ & 0.7 & Cooking Temperature $\left({ }^{\circ} \mathrm{C}\right)$ & 140 \\
Cooking Temperature $\left({ }^{\circ} \mathrm{C}\right)$ & 160 & Time to max. temperature $(\min )$ & 40 \\
Time to max. temperature $(\mathrm{min})$ & 40 & Time at max. temperature $(\min$ & 50 \\
Time at max. temperature $(\min$ & 120 & Liquor to raw material ratio & $5 / 1$ \\
Liquor to raw material ratio & $5 / 1$ & & \\
\hline
\end{tabular}

Cooking experiments were carried out on the species in a rotary digester with a capacity of 15 liters and high pressure resistant. Following the cooking processes, the pulps were washed with tap water to remove the black liquor, and the washed pulps were transferred to a $0.15 \mathrm{~mm}$ slotted screen.

\section{Secondary Fiber Production}

Pulping: Mixed office wastes were manually torn into $2 \times 2 \mathrm{~cm}$ pieces in accordance with the International Association of the Deinking Industry (INGEDE) (Method 11p -5.5) standard. The torn papers were then stored in resealable polyethylene bags, protected from light and heat, and subjected to pulping process. Hobart type pulping device was used in pulping process. The torn paper were wetted at $15 \%$ consistency and $45^{\circ} \mathrm{C}$ for 10 minutes. Then, the wetted papers were transferred to Hobart device and pulped at $15 \%$ consistency and $45{ }^{\circ} \mathrm{C}$ for 22 minutes $(2$ minutes in 1 level revolution, 20 minutes in 2 level revolution). The chemicals specified in the INGEDE standard were used during pulping. However, since cellulase enzyme is used, half of the chemical amounts given in the relevant standard were used.

Storage and Enzyme Application: The pulps taken from the Hobart type pulper were stored in a water bath for an hour at $5 \%$ consistency and $45^{\circ} \mathrm{C}$. Then, the pulps were transferred to the flotation unit for removal of their inks at the end of the specified time. Cellulase enzyme was applied to the pulps in order to reduce the amount of chemicals used in conventional deinking 
processes and to develop a new method. For this process, cellulase enzyme was used at $2.5 \mathrm{U} / \mathrm{g}$ and applied to the pulps during storage.

Flotation: Mixed office wastes were transferred to the flotation unit to remove their ink after the storage process was completed. Deinking operations were performed on a Degussa Flotation Unit, shown schematically (Cicekler \& Tutus, 2021) in Figure 1 below.

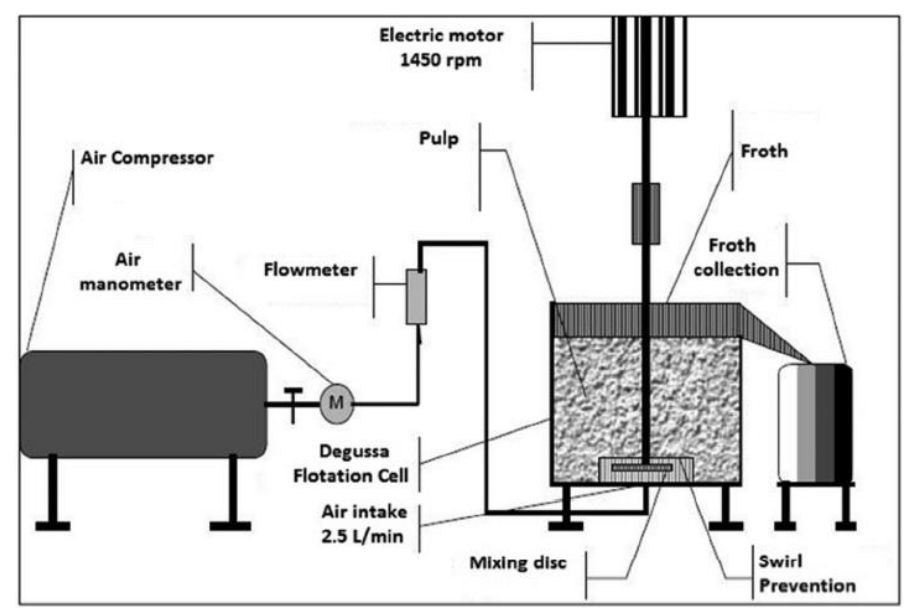

Figure 1. Schematic View of Degussa Type Flotation Unit

The flotation process was applied to the pulps in the flotation unit under the conditions given in Table 2 below.

Table 2. Flotation Conditions Applied to the Pulps

\begin{tabular}{lc}
\hline Conditions & Values \\
\hline Consistency & $0.8-1 \%$ \\
Temperature & $45^{\circ} \mathrm{C}$ \\
Flotation Time & $30 \mathrm{~min}$ \\
Revolution & $1450 \mathrm{rpm}$ \\
Water Hardness & $160 \mathrm{ppm}$ \\
Air Intake & $2.5 \mathrm{lt} / \mathrm{min}$ \\
\hline
\end{tabular}

The froth accumulated on the surface during the deinking process was removed with the help of scraper. After the flotation process was completed, the water was removed from the deinked pulp to be $25-30 \%$ solids.

\section{Bleaching Process}

The PF and SF were bleached with the conditions given in Table 3. Firstly, pre-enzyme (xylanase for PF and cellulase for SF) application (X) were applied to pulps. Preliminary experiments were carried out at different $\mathrm{pH}$, temperatures and times, and the obtained optimum condition is given in Table 3.

Table 3. Bleaching Conditions Applied to Primary and Secondary Fibers

\begin{tabular}{ccccc}
\hline $\begin{array}{c}\text { Enzyme Pre-treatment } \\
(\mathrm{X})\end{array}$ & $\begin{array}{c}\text { Oxygen Bleaching } \\
(\mathrm{O})\end{array}$ & Alkali Extraction & Hypochlorite & FAS Bleaching \\
& & $(\mathrm{E})$ & Bleaching & $(\mathrm{H})$
\end{tabular}




\begin{tabular}{lllll}
\hline BF: $15 \mathrm{U} / \mathrm{g}, \mathrm{WF}: 5$ & 7 bars & $\begin{array}{l}\text { NaOH charge: (Kappa no } \\
\text { pulps after oxygen } \\
\text { bleaching)x0.1+0.5 }\end{array}$ & $10 \% \mathrm{NaClO}$ & $0.4 \%$ FAS \\
U/g, SF: $10 \mathrm{U} / \mathrm{g}$ & & - & - & \\
$\mathrm{pH}: 7$ & $3 \% \mathrm{NaOH}, 0.5 \%$ & & $60.2 \% \mathrm{NaOH}$ \\
$40{ }^{\circ} \mathrm{C}$ & $\mathrm{MgSO}_{4}$ & $70{ }^{\circ} \mathrm{C}$ & $75^{\circ} \mathrm{C}$ \\
$10 \%$ Cons. & $100{ }^{\circ} \mathrm{C}$ & $12 \%$ Cons. & $10 \% \mathrm{Cons}$. & $5 \%$ Cons. \\
$60 \mathrm{~min}$ & $10 \% \mathrm{Cons}$. & $60 \mathrm{~min}$ & $60 \mathrm{~min}$ & 75 min \\
\hline
\end{tabular}

In order to obtain required optical properties for office paper production, XOEHEH bleaching stages were applied to PF and XOF bleaching stages were carried out to SF.

\section{Paper Production and Test}

The pulps obtained from brutia chip, wheat straw and mixed office waste papers were adjusted to $0.4 \%$ concentration in a 10 -liter mixer before the standard laboratory paper formation, and the freeness level determinations were carried out using the Schopper Riegler instrument according to the ISO 5267-1 method. Freeness level of pulps and grammages of the produced papers were adjusted to $25 \pm 3 \mathrm{SR}^{\circ}$ and $80 \pm 3 \mathrm{~g} / \mathrm{m}^{2}$, respectively. The blend ratios of the prepared pulps for office paper production were given in Table 4 below.

Table 4. Blend Ratios of the Primary and Secondary Fibers for Office Paper Production

\begin{tabular}{cccccccc}
\hline \multirow{2}{*}{ Experiment No } & BF & $\begin{array}{c}\text { WF } \\
\text { Blending Rates (\%) }\end{array}$ & SF & Experiment No & BF & WF & SF \\
& - & - & 100 & 11 & 20 & - & 80 \\
\hline 1 & - & 5 & 95 & 12 & 25 & - & 75 \\
3 & - & 10 & 90 & 13 & 30 & - & 70 \\
4 & - & 15 & 85 & 14 & 25 & 5 & 70 \\
5 & - & 20 & 80 & 15 & 20 & 10 & 70 \\
6 & - & 25 & 75 & 16 & 15 & 15 & 70 \\
7 & - & 30 & 70 & 17 & 10 & 20 & 70 \\
8 & 5 & - & 95 & 18 & 5 & 25 & 70 \\
9 & 10 & - & 90 & 19 & 100 & - & - \\
10 & 15 & - & 85 & 20 & - & 100 & - \\
\hline
\end{tabular}

The pulps were beaten in the Hollander device and test papers were produced in the Rapid Kothen RK-21 laboratory paper machine in the determined grammages.

The chemical, mechanical and optical properties of the produced papers were determined according to the standards given in Table 5.

Table 5. Chemical, Mechanical, Optical Tests and Standard Applied to the Papers.

\begin{tabular}{lc}
\hline Tests & Standards \\
\hline Kappa Number & TAPPI T236 \\
Viscosity $\left(\mathrm{cm}^{3} / \mathrm{g}\right)$ & TAPPI T230 \\
Breaking length $(\mathrm{km})$ & TAPPI T494 \\
Burst index $\left(\mathrm{kPa} . \mathrm{m}^{2} / \mathrm{g}\right)$ & TAPPI T403 \\
ISO whiteness $(\%)$ & ISO 11476 \\
ISO brightness (\%) & ISO 2469 \\
Opacity (\%) & TAPPI T519 \\
Yellowness (E313) & ASTM E313 \\
\hline
\end{tabular}


Ten test papers were produced from each blend and subjected to mechanical and optical tests. Three replicates were made for each sample in the kappa number and viscosity value determinations. Analysis of variance and Duncan test, which show the effect of blend ratios on optical and mechanical properties of papers, were also performed.

\section{RESULTS AND DISCUSSION}

\section{Properties of the Primary and Secondary Fibers}

Some chemical, mechanical and optical properties of PF and SF before and after bleaching processes were presented in Table 6.

Table 6. Some Chemical, Mechanical and Optical Properties of the PF and SF before Bleaching Processes

\begin{tabular}{|c|c|c|c|c|c|c|c|c|}
\hline $\begin{array}{l}\text { Fiber } \\
\text { Type }\end{array}$ & $\begin{array}{l}\text { Kappa } \\
\text { No }\end{array}$ & $\begin{array}{l}\text { Viscosity } \\
\left(\mathrm{cm}^{3} / \mathrm{g}\right)\end{array}$ & $\begin{array}{c}\text { Breaking } \\
\text { Length }(\mathrm{km})\end{array}$ & $\begin{array}{l}\text { Burst Index } \\
\left(\mathrm{kPa} \cdot \mathrm{m}^{2} \mathrm{~g}^{-1}\right)\end{array}$ & $\begin{array}{c}\text { Brightness } \\
\text { (ISO\%) }\end{array}$ & $\begin{array}{l}\text { Whiteness } \\
\text { (ISO\%) }\end{array}$ & $\begin{array}{l}\text { Yellowness } \\
\text { (E313) }\end{array}$ & Opacity (\%) \\
\hline \multicolumn{9}{|c|}{ Before Bleaching Process } \\
\hline $\mathrm{BF}$ & 42.6 & 1288 & 7.89 & 4.97 & 25.6 & 17.0 & 41.9 & 98.0 \\
\hline WF & 41.9 & 896 & 6.12 & 3.39 & 28.7 & 43.4 & 48.3 & 97.6 \\
\hline SF & 13.4 & 746 & 3.06 & 2.07 & 71.8 & 89.2 & -29.4 & 96.2 \\
\hline \multicolumn{9}{|c|}{ After Bleaching Process } \\
\hline $\mathrm{BF}$ & 15.7 & 1087 & 2.57 & 1.45 & 80.0 & 77.1 & 4.67 & 64.9 \\
\hline WF & 13.5 & 582 & 3.29 & 1.41 & 80.5 & 76.2 & 4.86 & 65.9 \\
\hline SF & 6.20 & 677 & 2.40 & 1.45 & 80.7 & 94.0 & -20.2 & 95.8 \\
\hline
\end{tabular}

According to Table 6, the mechanical properties of the PF and SF decreased significantly after the bleaching treatments. During the bleaching processes, the viscosity values of the fibers show a decrease. Bleaching agents used in the bleaching process applied to pulp to remove lignin or to lighten its color affect carbohydrates such as cellulose and hemicellulose as well as lignin. Therefore, bleaching chemicals degrade carbohydrates as well as react with lignin (Dence \& Reeve, 1996; Kirci et al., 2004). Due to these degradations in the cellulose chains, pulps viscosity values and thus mechanical properties were adversely affected. However, the optical properties except for the opacity values of the fibers improved significantly after bleaching processes. Bleaching of fiber reduced the light adsorption coefficient by eliminating light absorbing colored groups, which also decreased the paper opacity, according to the Kubelka-Munk theory (Levlin and Söderhjelm, 1999). The mechanical and optical properties of these fibers are sufficient for the office paper production.

\section{The Mechanical and Optical Properties of the Office Papers}

Some mechanical and optical properties of the office papers produced from blends of fibers obtained from mixed office wastes, wheat straws and brutia chips were given in Table 7 below. 
Table 7. The Mechanical and Optical Properties of the Office Papers Produced with PF and SF Blends

\begin{tabular}{|c|c|c|c|c|c|c|c|c|}
\hline 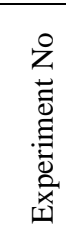 & 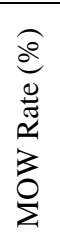 & $\begin{array}{l}\text { ô } \\
0 \\
\frac{0}{2} \\
\frac{1}{3}\end{array}$ & 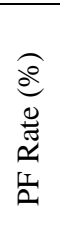 & 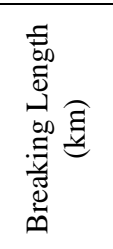 & 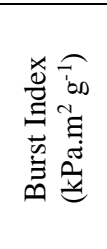 & 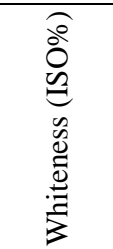 & 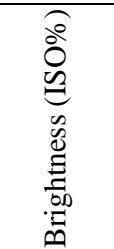 & 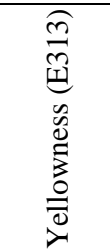 \\
\hline 1 & 100 & - & - & $2.40 \mathrm{~b}$ & $1.45 \mathrm{~b}$ & $80.65 a$ & $94.02 \mathrm{a}$ & $-20.16 a$ \\
\hline 2 & 95 & 5 & - & $2.70 \mathrm{ba}$ & $1.55 \mathrm{ba}$ & $80.64 a$ & $93.17 \mathrm{a}$ & $-18.94 b$ \\
\hline 3 & 90 & 10 & - & 3.06ba & $1.57 \mathrm{ba}$ & 80.06ba & $92.08 \mathrm{~b}$ & $-18.27 c$ \\
\hline 4 & 85 & 15 & - & $2.44 b$ & $1.51 \mathrm{ba}$ & $80.28 \mathrm{ba}$ & $91.94 \mathrm{~b}$ & $-17.68 d$ \\
\hline 5 & 80 & 20 & - & $2.83 \mathrm{ba}$ & $1.53 \mathrm{ba}$ & $80.13 \mathrm{ba}$ & $91.30 \mathrm{cb}$ & $-16.95 \mathrm{e}$ \\
\hline 6 & 75 & 25 & - & $3.24 \mathrm{a}$ & $1.52 \mathrm{ba}$ & $79.98 \mathrm{~b}$ & $90.70 \mathrm{c}$ & $-16.31 f$ \\
\hline \multirow[t]{2}{*}{7} & 70 & 30 & - & $3.22 \mathrm{a}$ & $1.61 \mathrm{a}$ & $79.69 b$ & $89.69 d$ & $-15.29 \mathrm{~g}$ \\
\hline & & Sig. & & .067 & .153 & .026 & .000 & .000 \\
\hline 1 & 100 & - & - & $2.40 \mathrm{c}$ & $1.45 \mathrm{ba}$ & $80.65 a$ & $94.02 \mathrm{a}$ & $-20.16 a$ \\
\hline 8 & 95 & - & 5 & $3.01 \mathrm{a}$ & $1.49 \mathrm{ba}$ & $80.28 \mathrm{ba}$ & $92.70 \mathrm{~b}$ & $-18.83 b$ \\
\hline 9 & 90 & - & 10 & $2.81 \mathrm{ba}$ & $1.55 \mathrm{a}$ & $80.12 \mathrm{ba}$ & $91.84 \mathrm{c}$ & $-17.81 \mathrm{c}$ \\
\hline 10 & 85 & - & 15 & $2.94 \mathrm{ba}$ & $1.39 \mathrm{cba}$ & $80.23 b$ & $91.32 \mathrm{c}$ & $-16.82 d$ \\
\hline 11 & 80 & - & 20 & $2.58 \mathrm{cb}$ & $1.34 \mathrm{cb}$ & $79.92 \mathrm{cb}$ & $90.46 \mathrm{~d}$ & $-16.12 d$ \\
\hline 12 & 75 & - & 25 & $2.63 \mathrm{cb}$ & $1.34 \mathrm{cb}$ & $79.88 \mathrm{cb}$ & $89.93 \mathrm{~d}$ & $-15.32 \mathrm{e}$ \\
\hline \multirow[t]{2}{*}{13} & 70 & - & 30 & $2.65 \mathrm{cba}$ & $1.22 \mathrm{c}$ & $79.56 \mathrm{c}$ & $89.10 \mathrm{e}$ & $-14.59 f$ \\
\hline & & Sig. & & .036 & .007 & .006 & .000 & .000 \\
\hline 1 & 100 & - & - & $2.40 \mathrm{~d}$ & $1.45 \mathrm{ba}$ & $80.65 a$ & $94.02 \mathrm{a}$ & $-20.16 a$ \\
\hline 14 & 70 & 25 & 5 & $2.74 d c$ & $1.32 \mathrm{~b}$ & $79.36 \mathrm{c}$ & $88.24 \mathrm{~d}$ & $-13.63 e$ \\
\hline 15 & 70 & 20 & 10 & $2.99 \mathrm{cb}$ & $1.37 \mathrm{ba}$ & $79.56 \mathrm{cb}$ & $88.72 \mathrm{~d}$ & $-14.02 \mathrm{e}$ \\
\hline 16 & 70 & 15 & 15 & $2.94 \mathrm{cb}$ & $1.30 \mathrm{~b}$ & $79.87 \mathrm{~b}$ & $89.48 \mathrm{c}$ & $-14.65 d$ \\
\hline 17 & 70 & 10 & 20 & $3.25 \mathrm{ba}$ & $1.42 \mathrm{ba}$ & $79.57 \mathrm{cb}$ & $90.07 \mathrm{~b}$ & $-15.81 \mathrm{c}$ \\
\hline \multirow[t]{2}{*}{18} & 70 & 5 & 25 & $3.58 \mathrm{a}$ & $1.51 \mathrm{a}$ & $79.86 \mathrm{~b}$ & $89.98 \mathrm{cb}$ & $-15.36 b$ \\
\hline & & Sig. & & .005 & .092 & .008 & .000 & .000 \\
\hline 19 & - & - & 100 & 2.57 & 1.45 & 80.0 & 77.1 & 4.67 \\
\hline 20 & - & 100 & - & 3.29 & 1.41 & 80.5 & 76.2 & 4.86 \\
\hline
\end{tabular}

* Mean values with the same lower-case letters are not significantly different at 95\% confidence level according to Duncan's mean separation test.

Density $\left(0.61-0.62 \mathrm{~g} / \mathrm{cm}^{3}\right)$ and bulkiness $\left(1.66-1.67 \mathrm{~cm}^{3} / \mathrm{g}\right)$ values as the physical properties of the produced papers were also examined, but they were not discussed separately because the values of all papers were similar.

Mechanical Properties: In the office paper production, it has been observed that there is an increase in the breaking length by adding WF in certain proportions to the SF. With the addition of $30 \% \mathrm{WF}$, the breaking length and bursting index increased by $34.2 \%$ and $4.8 \%$, respectively. According to the results of the analysis of variance, it is seen in Table 7 above that the ratio of WF did not have a significant effect on the mechanical properties of the office paper. According to the Duncan test, it was determined that there were significant differences in the use of WF at the rate of $25 \%$ and $30 \%$ on the breaking length, at the limit of 5\% error probability compared to other rates. It has been determined that there is a significant difference between the use of $\mathrm{WF}$ at the rate of $30 \%$ on the burst index of the WF incorporation rate compared to the other ratios.

In the production of office paper, the addition of BF up to $15 \%$ has a positive effect on its mechanical properties, while adding more than this rate decreases the mechanical properties again. The highest value in breaking length was obtained with the addition of $5 \% \mathrm{BF}$, and the highest value in burst index was obtained with the addition of $10 \% \mathrm{BF}$. According to the results of the analysis of variance, it is seen in Table 7 above that the ratio of BF has a significant 
effect on the mechanical properties of the paper. According to the Duncan test, it was determined that there was a significant difference in the use of $5 \% \mathrm{BF}$ on the breaking length and $10 \%$ on the burst index compared to other ratios.

According to the analysis of variance, it is seen in Table 7 above that the blend ratio of WF and $\mathrm{BF}$ did not have a significant effect on the mechanical properties of the office papers, except for the breaking length $(\mathrm{p}<0.005)$. According to the Duncan test, it was determined that there were significant differences on the breaking length and burst index in the use of $25 \%$ of the $\mathrm{WF}$ and $5 \%$ of $\mathrm{BF}$ at the limit of $5 \%$ error probability compared to the other ratios.

In the office paper production, when MOW are mixed with BF and WF, the best mechanical properties were obtained with the addition of WF. In Table 7, breaking lengths and burst indices of office papers produced from BF (100\%) and WF (100\%) were determined as 3.29-2.57 km and 1.41-1.45 $\mathrm{kPa} . \mathrm{m}^{2} \mathrm{~g}^{-1}$, respectively. One of the most important factors affecting tensile strength is the number and quality of the fiber-fiber bond (Casey, 1960). It is thought that the fiber length plays an important role on the breaking length of the papers. However, some researchers believe that small changes in fiber lengths have little effect on breaking strength. Fiber width rather than fiber length is also effective on tensile strength. Papers with short fiber length and low fiber width have high breaking length (Eroglu \& Usta, 2004). As a matter of fact, the breaking lengths of WF were found to be approximately $28 \%$ higher than that of BF, despite their short fiber content. As stated above, not only fiber length but also fiber widths are effective on breaking length. There is no significant difference between burst indices. One of the factors affecting burst resistance is fiber length and the other is internal bonding (Clark, 1978; Eroglu, 2003). Although, BF are long fiber and WF are short fiber, it is thought that the similarity between the burst values is due to the better internal bonding in WF.

Optical Properties: It has been observed that optical properties are reduced by adding WF in certain proportions to the pulp obtained from MOW in the office paper production. With the addition of $30 \%$ WF to MOW, whiteness, brightness and yellowness values decreased by $1.2 \%$, $4.6 \%$ and $24.2 \%$, respectively. According to the results of the analysis of variance, it is seen in Table 7 above that WF and its ratio have a significant effect on the optical properties of the papers. According to the Duncan test, there are no significant differences between the use of MOW and $10 \%, 15 \%$ and $20 \% \mathrm{WF}$ at the rates of 0 and $5 \%$ on the whiteness values, and there are significant differences between the use of $25 \%$ and $30 \%$ WF. It has been determined that there are significant differences between the use of 10\%, 15\%, 20\%, 25\% and 30\% WF and the use of $0 \%$ and $5 \%$ in the brightness values. It was observed that there were significant differences between all ratios in the yellowness values of the papers.

According to the results of the analysis of variance applied in Table 7, it is understood that the $\mathrm{BF}$ ratios added to the MOW have a significant effect on the optical properties of the papers. It has been determined that there is no difference between the use of BF at the rates of " $20 \%$ 25\%-30\%", "5\%-10\%-15\%-20\%-25\%" and "0\%-5-10\%". In terms of yellowness values, it was determined that the use of $15 \%$ and $20 \% \mathrm{BF}$ did not have significant differences among themselves, while other ratios had significant differences on the yellowness values. According to the analysis of variance, it is stated in Table 7 that the BF and WF added to the SF at certain rates have a significant effect on the optical properties of the office papers. It is understood that the use of $\mathrm{BF}$ and $\mathrm{WF}$ in the office paper production has a negative effect on the optical properties. 
When the optical properties of the papers produced from SF (100\%), BF (100\%) and WF $(100 \%)$ are compared, it is seen in Table 7 that the optical properties of the papers produced from SF are quite high. The main reasons for this are that MOW contain substances that improve optical properties such as optical whitener, indigo dye and filler. These substances have a significant effect on the brightness and yellowness values (Sener \& Gol, 1990).

According to TS 11610:2017 standard, some minimum mechanical properties and brightness values of office papers $\left(80 \mathrm{~g} / \mathrm{m}^{2}\right)$ are given in Table 8 below.

Table 8. Minimum Mechanical and Optical Properties for Office Paper in Accordance with TS 11610:2017

\begin{tabular}{|c|c|c|}
\hline Mechanical and Optical Properties & Unit & Value \\
\hline Breaking Length (CD-MD) & meter & $2000-4000$ \\
\hline Burst Index & $\left(\mathrm{kPa} \cdot \mathrm{m}^{2} \mathrm{~g}^{-1}\right)$ & 1.3 \\
\hline Brightness & $\mathrm{ISO} \%$ & 86 \\
\hline
\end{tabular}

When the office papers produced by BF, WF and SF blends were examined in accordance with the TS 11610:2017 standards specified in Table 8, the appropriate blend ratios for office paper production were given in Table 9 below.

Table 9. PF and SF Blend Ratios in Accordance with Standards in Office Paper Production

\begin{tabular}{cccc}
\hline & $\begin{array}{c}\text { MOW } \\
(\%)\end{array}$ & WF & BF \\
$(\%)$ & $(\%)$ \\
\hline 1 & 90 & 10 & - \\
2 & 75 & 25 & - \\
3 & 70 & 30 & - \\
4 & 95 & - & 5 \\
5 & 70 & 5 & 25 \\
6 & 70 & 10 & 20 \\
\hline
\end{tabular}

According to Table 9, with six different blend ratios from PF and SF, office papers can be produced in accordance with standards.

\section{CONCLUSIONS}

With this study, pulping, deinking and three-stage bleaching processes are sufficient to recycle mixed office wastes and reuse in the office paper production. Therefore, considering the chemicals used in the office paper production from mixed office wastes and the amount of energy consumed, less cost is required compared to imported bleached cellulose. Secondary fibers shorten and become brittle during recycling. For this reason, their strength properties are lower than primary fibers. Strength losses that may occur in the office paper production from mixed office wastes can be eliminated by adding strength chemicals or primary fiber. Bleached cellulose, which will be produced from wheat straws and brutia wood, which is also used in this study and which is produced and grown in large quantities in Turkey, can be added to secondary fibers in certain proportions, and the decreasing resistance properties during recycling can be eliminated. 


\section{AUTHOR CONTRIBUTIONS}

Mustafa Çiçekler: Designing the research, writing and reviewing the manuscript, obtaining the materials for the analysis and conducting the analysis. Ahmet Tutuş: Designing the research, writing and reviewing the manuscript and supervising.

\section{ACKNOWLEDGEMENT}

The Kahramanmaras Sutcu Imam University, Research Project Coordination Unit, supported this research under project number 2014/3-33 D.

\section{REFERENCES}

Bajpai, P., Bajpai, P. K., \& Kondo R. (1999) Pulp Bleaching with Xylanases. In: Biotechnology for Environmental Protection in the Pulp and Paper Industry. Springer, Berlin, Heidelberg.

Borchardt, J. (1999) An introduction to Deinking Chemistry. In Doshi, M. R. and Dyer, J. M., (Eds.), Paper Recycling Challenge Vol. 2: Deinking \& Bleaching, Doshi \& Associates Inc., Appleton WI, 18-30.

Brothers, K. J., Krantz, P. J., \& McClannahan, L. E. (1994) Office paper recycling: A function of container proximity. Journal of Applied Behavior Analysis, 27(1), 153-160.

Casey, J. P. (1960) Pulp and Paper (Vol:3). Interscience Publisher Inc., Newyork.

Cicekler, M., \& Tutus, A. (2021) Effects of cellulase enzyme in deinking of Solvent-Based inks from mixed office wastes, Biocatalysis and Biotransformation, 39(2), 152-160.

Clark, J. A. (1978) Pulp Technology, Mille Freeman Publications, Inc. California.

Cleveland, F. C. (1993) Pulping of Secondery Fibre. In Secondery Fibre Recycling, Edited by Spangenberg. Tappi Press, Atlanta, 91-100.

Confederation of European Paper Industries (CEPI). Annual statistics reports for Europe. (2021) https://www.cepi.org/policy-area/sustainability-circularity/ Accessed 15.05.2021.

Dence, C. W., \& Reeves, D. W. (1996) Pulp Bleaching-Principles and Practice, Tappi Press, Atlanta, $512 \mathrm{p}$.

Eom, T. J., \& Ow, S. S. K. (1990) Process for Removing Printing Ink from Wastepaper. German Patent GB 3,934,772.

Eroglu, H., \& Usta, M. (2004) Paper and cardboard production technology textbook. Esen Ofset Printing, Trabzon, Turkey.

Ferguson, L. D. (1992) Deinking Chemistry: Part 2, Tappi Journal, 75(8), 49-57.

Food and Agriculture Organization of the United Nations (FAO). (2021) http://www.fao.org/faostat/en/\#data/FO Accessed 15.05.21.

Kirci, H., Pesman, E., Kalyoncu, E. E. (2004) Sodium Perborate Monohydrate Reinforced Oxygen Delignification Stage of Kraft Pulps. In: Proc. $2^{\text {nd }}$ International Boron Symposium, pp. 339-343, 23-25 Semtember, Eskişehir, Turkey.

Levlin, J. E., \& Söderhjelm, L. (1999). Pulp and Paper Testing. In Papermaking Science and Technology, Fapet Oy, Helsinki, Finland, 175-176.

McCool, M. A. (1993) Flotation Deinking. In Secondery Fibre Recycling, Edited by Spankgenberg, R.J. Tappi Pres, Atlanta. 
Morel, P. L. (1989) Secondery Fibre for Newsprint, Proceedings of Tappi Pulping Conference, Tappi Pres, Atlanta, 367-372.

Olson, C. R., Richmann, S. K., Sutman, F. J., \& Letscher, M. B. (1993) Deinking of laserprinted stock using chemical densification and forward cleaning, Tappi Journal, 76(1), $136-144$.

Pesman, E. (2010) Determination of ink removal and bleaching properties of old news and magazine papers, Doctoral dissertation, Karadeniz Technical University, Trabzon, Turkey.

Scheldorf, J. M., \& Strand, B. C. (1996) Simulation of Ink Removal at a Newsprint Deinking Facility, Tappi Journal, 79(12), 135-141.

Sener, M. E., \& Gol, I. 1990. The use of brighteners in textiles, Journal of Textiles and Engineer, 4(22), 211-217.

Senior, D. J., \& Hamilton, J. (1991) Use of xylanase to decrease the formation of aox in kraft pulp bleaching. In: Proceedings Environ. Conf. of the Technical Section, Canadian Pulp and Paper Association. Quebec, Canada, p. 63.

Thibault, L., Tolan, J., White, T., Yee, E., April, R., \& Sung, W. (1999) Use of an engineered xylanase enzyme to improve ECF bleaching at weyenhaeuser Prince Albert. In: 85th Annual Meeting, Montreal, Canada, p. B263.

Tolan, J. S., \& Canovas, R. V. (1992) The use of enzymes to decrease the chlorine requirements in pulp bleaching, Pulp Pap. Can., 93(5), 39.

Tsatsis, D. E., Papachristos, D. K., Valta, K. A., Vlyssides, A. G., \& Economides, D.G. (2017) Enzymatic deinking for recycling of office waste paper, Journal of Environmental Chemical Engineering, 5(1), 1744-1753.

Viesturs, U., Leite, M., Eisimonte, M., Eremeeva, T., \& Treimanis, A. (1999) Biological deinking technology for the recycling of office waste papers. Bioresource Technology, 67(3), 255-265.

Welt, T., \& Dinus, R. J. (1995) Enzymatic deinking-a review, Prog. Paper Recycl., 4(2), 3647.

Woodward, J., Stephan, L. M., Koran, L. J., Wong, K. K. Y., \& Saddler, J. N. (1994) Enzymatic separation of high-quality uninked pulp fibers from recycled newspaper, Biotechnology, 12(9), 905.

Zhan, H., Yue, B., Hu, W., \& Huang, W. (2000) Kraft reed pulp TCF bleaching with enzyme treatment, Cellulose Chem. Technol., 33(1-2), 53-60. 